\title{
The Response of Some Scholars To Joseph Schacht's Thesis Regarding The Authenticity of Traditions
}

\author{
Oleh : Akh. Minhaji \\ (McGill Univer'sity, Canada)
}

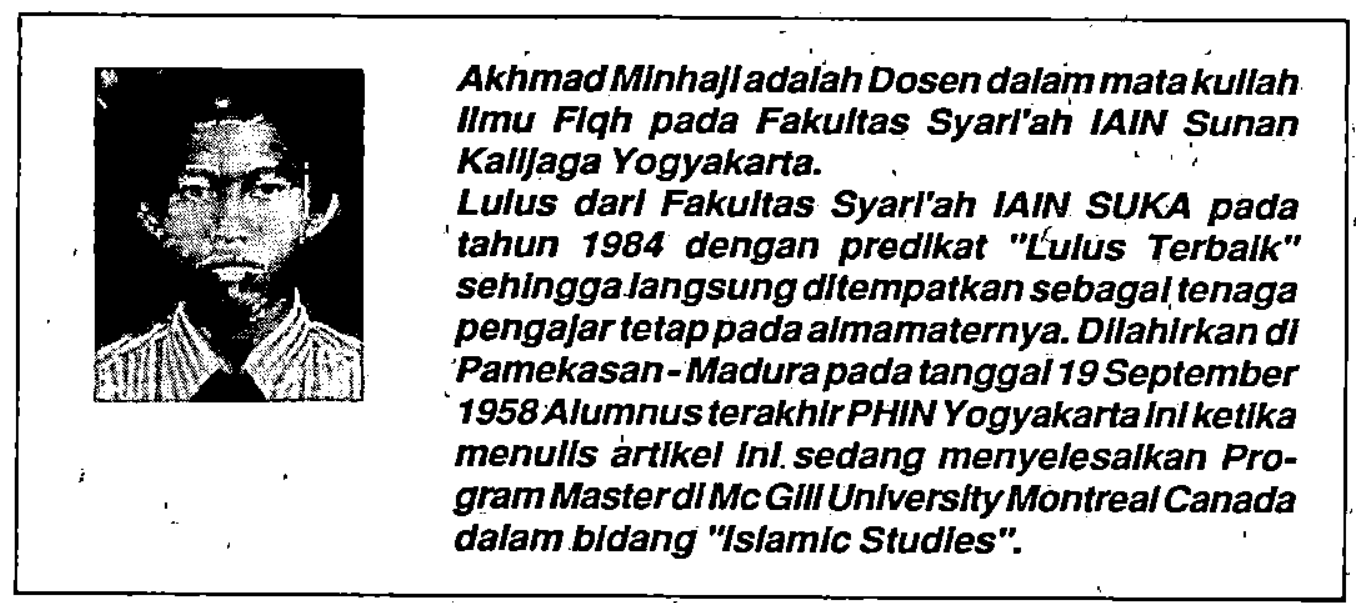

Joseph Schacht's "discovéry" regarding the authenticity of Islamic tradition-literature made a tremeńdous impression on , some Islamic - scholars. When Schacht published his The Origins of Muhammadan Jurisprudence in 1950, the book immediately met with immense approval. ${ }^{1}$ His thesis, which is concerned with (among other topics) the authenticity of legal traditions, has generated one of the most'serious debates among Islamic scholars. ${ }^{2}$, One of his most important

1 See the following remarks : $W$. Montgomery Watt, JRAS (1952), 91 : a "landmark a...study likely to be the basis of ail future work on the subject." J.N.D. Anderson, Well des Islams 2 (1952), 136 : "a new land mark ...The validity of his main contentions appear inescapable." James Robson, The Muslim World 42 (1952), 62: "one can only admire the critical insight which has enable the author to come to his conclusion and support it 'so convincingly." H. Ritter, Oriens 4 (1951), 312: "a thorough methodical and highly original book." Arthur Jeffery, Middle East Journal 5 (1951), 393 : "...meticulous in detail, sober in judgment, and clear in exposition."

2 Joseph Schacht (1902 - 1969) has devoted a considerable part of his career to study the early history and development of Islamic juristic thought: He has /written quite a number of scholarly works to express his thesis. nonetheless, it is clear that his main thesis is elaborated in his two famous books, The Origins of Muhammadan Jurisprudence and An Introduction to Islamic Law, both of which works possess all the atributes of originality and profound thought. Brunschvig has tried to make a detailed list of Schacht's scholarly publications in Studia Islamica (volume 31,1970 ) divided into twelve different sections. An excellent annotated bibliography of those publications is contained in Schacht's An Introduction' to Islamic Law, first published in 1964. 
conclusions, and one which may perhaps give pain to pious Muslims, is his notion that "we shall not meet any legal tradition from the Prophet which can positively be considered authentic." 3 What is more, Schacht himself used to acknowledge right up until his death in 1969, that his conclusions only reconfirm and elaborate the grand theory set forth by his predecessor, Ignaz Goldhziher. ${ }^{4}$

Some scholars, however, have addressed various responses to Schacht's thesis, some of the more prominent ones being Fazlur Rahman, Nabia Abbott, Fuat Sezgin, M. Mustafa Azami, and Zafär Ishạa 'Anșāri. The present essay is an endeavour to critically examine the response of these scholars to Schacht's thesis regarding the authenticity of legal traditions.

- Fazlui Rahman 5 is one of many Muslim scholars who have criticized Schacht's thesis concerning the authenticity of traditions. According to Rahman, Schacht has failed to draw a clear conceptual distinction between sunnah and hadi th. As a result, Rahman emphasizes, Schacht come to the conclusion that the sunnah of the Prophet, which is considered one of the main sources of Islamic law, is not really the sunnah of the Prophet, but rather 'a living tradition' of a certain local Muslim society. ${ }^{6}$ For this reason, Rahman starts his analysis by providing a clear distinction between sunnah and hadith, and then brings up some important implications of this distinction.

Generally speaking, Rahman agrees with some scholars who are of the opinion that the birth of Islam had almost nothing to do with pre-Islamic Arab tradition. .However, it is also clear and undeniable that many basic aspects of Islamic teaching were derived from pre-Islamic Árab tradition, and the concept of sunnah is,

3 Joseph Schacht, The Origins of Muhammadan Jurisprudence (Oxford : Clarendon Press, 1959), 149.

4 Ibid., 4-5. See also his article "A Revaluation of Islamic Traditions," JRAS (1949): 143; Ritter, review of The Origins, 309; Robson, review of the same book, 63; David F. Forte, "Islamic Law : The Impact of Joseph Schacht," Loyola Los Angeles International and Comparative Law Annual 1,(1978) : 2 .

5 He was the first Director of Central Institute of Islamic Research, Karachi-Pakistan. He was also Professor of Islamic thought in the Department of Near Eastern Languages and Civilizations at the University of Chicago. He is, according to George Weckman, "an eloquent spokesman for enlightened change within Islam." He was (is) well-known by most of Muslim scholars, Denney writes : "A measure of this leading thinker's [Rahman] impact is that wherever I have traveled in the world-whether here in North America, or to Egypt, Jordan, the West Bank, the Peninsula, Bangladesh, Pakistan, Malaysia, Indonesia, or Europe- I have never met a Muslim scholar or other specialist on Islam who has not heard of Fazlur Rahman or who is neutral about his contributions to the making sense of life in Islamic ways" (see Frederick Mathewson Denny, "Fạzlur Rahman : Muslim Intellectual," The Muslim World LXXIX, April 1989 : 101). He unfortunately passed away in 1988.

6 Fazlur Rahman, Islamic Methodology in History (Karachi : Central Institute of Islamic Research, 1965), 5. See also his Islam, 45 - 7; his "Some Issues in the Ayyūb Khān Era," in Essays on Islamic Civilization, ed. Donald P. Little (Leiden : E.J. Brill, 1976), 285. 
according to Rahman, one of the clear examples in point. ${ }^{\text {? }}$

Rahman provides a definition of sunnah in order to distinguish it from the concept of hadith. Sunnah, according to him, is a "trodden path,"8 an "exemplary conduct," 9 or a "model pattern of behaviour," 10 and he agrees with the view dominant among more recent Western scholars that "Sunnah denotes the actual practice which, through being long established over successive generations, gains the status of normativeness and becomes' 'Sunnah'."11

There is no doubt, in Rahman's view, that Muhammad, as a Prophet, laid down some important rules of daily life as the guiding principles of his ummah. "Rejection of this natural phenomenon," says Rahman, "is tantamount to a grave irrationality, a sin against history." 12 However, Rahman reminds us, the phrase "Prophetic sunnah" does not denote exclusively the exemplary conduct of the Prophet, but rather a continuous and progressive interpretation of his ideal examples "in terms of the new situation." Hence, the Prophetic sunnah contains "not only the general Prophetic Model but also regionally standardized interpretations of that Model."13

Hadith, according to Rahman, is a religious term wich is different but which cannot be "divorced" from sunnah. Hactith literally means "tradition," 14 and is "nothing but a reflection in' a verbal mode" of the actual practice (sunnah). ${ }^{15}$ Therefore, the Prophetic hadi th is nothing but a reflection in a verbal mode of the Prophetic sunnah. In other words, the
Prophetic hadith is the carrier of the Prophetic sunnah.

In addition, Rahman accepts Schacht's conclusion that according to historical examination most, if not all, of the Prophetic hadt ths which are accepted as the second authoritative source of Islamic doctrine, were fabricated by later generations. ${ }^{16}$ Nonetheles, it is going too far to conclude, in Rahman's view, that there is no intimate connection between the later hadi ths compiled in the six canonical books and the hadi ths of the Prophet. For, as stated previously, while sunnah is a continuous and progressive interpretation of the ideal examples (of the Prophet), hadith is the carrier of the sunnah, and

7 Rahman, op. cir. 1-4. See also his Islam. 44. Another example given by Rahman is the practice of polygamy (see his "The Status of Women in Islam," in Separale World : Studies of Purdah in South Asia, eds. Hanna Papanek and Gail Minault, Delhi : Kay Kay Printers, 1982. 300; his Islam, 29).

8 Rahman, Islam, 44.

9 Rahman, op. cil., 2.

10 Rahman, Isiam, 3.

11 Rahman, Islamic Methodology, 1.

12 Ibid., 32.

'13 Ibid., 27, 74.

14 Rahman, Islam, 14.

15 Rahman, op. cit., 74.

16 Ibid., 33. For the examples of the fabricated tradition, see ibid., 17, $19-20$. 
represents "the interpreted spirit of the Prophetic teaching. ${ }^{\text {"17 }}$

John Burton makes Rahman's thesis an object of criticsm, and at the same time he supports Schacht's. ${ }^{18}$. Rahman, according to Burton, has tried to connect the later hadi ths (and sunnahs) with the Prophetic hadi ths (and sunnahs). However, Rahman cannot, avoid the consequence of his own thesis-that it is difficult, if not impossible, to distinguish between the content of hadt th as the continuation of the Prophetic hadt th and the content of hadith which was really fabricated by later generations in order to. support their ideas. The situation is more complex, for it is a historical fact that political, theological, and legal viewpoints deeply.influenced the appearance of certain hadi ths. 19. To put it differently, by no means are we able to distinguish the hadi th (sunnah) which really relies upon the Prophetic teaching from the hadith (sunnah) which was forged by certain' people to support their vested-interests or which were the result of, to use Rahman's words, the "tremendous struggles and conflicts against heresies and extreme sectarian opinion." 20 Historical examination demonstrates that many hadiths are spurious and were forged by classical Muslim scholars and, according to Rahman himself, have nothing to do with Prophetic hadi th. ${ }^{21}$ On this point, according to Burton, Rahman has basically failed not only to realize the distinction between the concept and the content of hadith or sunnah, but also to "grasp the theses of .... Schacht." 22

In short, Rahman's refutation of Schachts's main thesis that the Prophetic hatith (sunnah) is a second century concoction of the Muslim scholars is somehow unclear. For eventhough he has shown the existence of the so-called genuine hadith, Rahman failed to give a clear answer how to distinguish. the genuine hadith from the forged one. On the contrary, through a variety of data, Schacht successfully investigates the historical development of traditions and comes to the succinct conclusion that the socalled Prophetic tradition is fabricated by later generations and has nothing to do with the Prophet himself. He even traces the origin of individual traditions.

In 1967 Nabia Abbott ${ }^{23}$ published her Studies in Arabic Literary Papyri, volume 2 of which concerned with Qur'anic commentary and traditions. The purpose of this book does not seem to be to dispute Schacht's thesis directly. Nevertheless, when she come to the conclusion that the

17. Ibid., 29.

18 See his review of Islam, by Fazlur Rahmân, in BSOAS 31 (1968) : 392 - 5:

19 lbid, $393-4$

${ }^{20}$ Rahman, op. cit, 44-5

21 See page 5 footnote 17 above

22 Burton, review of Islam, 393-4.

23 She was the first women faculty member of the Departiment of Oriental Languages and the Oriental Institute of the University of Chicago. She became Travelling Fellow and Research Associate (1933-7), Assistant Professor (193843), Associate Professor (1943-9), Profèssor of Islamic Studies (1949-63), and Professor Emeritus in 1963 (see Muhsin Mahdi in the "Foreword" of Journal of Near Eastern Studies 40, July, 1981) 
science of traditions is not simply an offshoot of the developing legal interests of the community, and that triditions were transmitted, both orally and in writing, from the very beginning of the first century of Islam, ${ }^{24}$ it is clear that she | seriously challenges Schacht's thesis regarding the autheticity of the Prophetic traditions. This tendency is obviously emphasized by her subsequent article "Hadf th Literature : Collection and Transmission of Hadith." 25 In this article, which depends heavily on her research in Arabic Literary Papyri, she argues that the collection of traditions "was begun in "Muhammad's lifetime" and was handed down to the following generations until the era of the six famous canonical collections.

Abbott's research has yielded some important results which have, according to Charles J. Adams, "set the stage for the nect steps" in the discussion of the authenticity of the Prophetic traditions. ${ }^{26}$

The era chosen by Abbott to verify her conclusion that the traditions originated in the lifetime of Muhammad fits into four general periods. The first is the period during Muhammad's lifetime. The second is the period after Muhammad's death when there was a growth in the number of traditions widely spread by the Companions until the coming to the Umayyad period. The third is the era of the Umayyads where the key position of Ibn Shihāb Muhammad b. Muslim alZuhri (d. 124/742) is mostly emphasized. In the fourth period the formal and collections of traditions appeared in the canonical books.

It is impossible here to discuss in detail Abbott's elaboration of each period which, at least according to Robson, ${ }^{27}$ is well designed to support her conclusion. Nonetheless, some important points must be taken into account, and one of the crucial issues concems the written data given by Abbott which are clearly dated 'only after the first century of Islam. The absence of written documents' during the first century of Islam encourages the appearance of intellectual speculation among Islamic scholars to solve the "mystery" surrounding the era. Therefore, the result of Abbott's investigation is nothing but one among other intellectual speculations by scholars. Because of this very reason, 'perhaps, Wansbrough, after evaluating her papyri documents, points out that "this is surely $z a^{\prime} a m$, not burhän." 28

Moreover, although Abbott, has successfully, demonstrated the whole

24 See her Studies in Arabic Literay Papyri vol. 2, Qur'änic Commentary and Tradition (Chicago : The University of Chicago Press, 1967), 2. See also Adams, "Islamic Religious Tradition," in The Study of the Middle East : Research and Scholarship in the Humanities and Social Sciences, ed. L. Binder (New York : John Willey \& Sons, 1976), 66.

25 In Arabic Literature to the End of the Umayyad Period, eds. A.F.L. Beeston and others (Cambridge: Cambridge University Press, 1983), $289=98$

26 Adams, "Religious Tradition," 66.

27 James Robson, review of Studies in Arabic Literary Papyri, volume 2, by Nabia Abbott, in Journal of Near Eastern Studies 27 (1968) : 143 4.

28 J. Wansbrough, review of Studies in Arabic Literary Papyri, volume 2, by Nabia Abbott, in BSOAS 31 (1968) : 614 . 
picture of the traditions as chronologically genuine, she cannot avoid the evidence that some of the traditions are forgeries. "[T]here were few dishonest and unscrupulous men," she says, "responsible for an occasional deception or forgery or, as is alleged particularly in the case of sectarians, for wholesale fabrication....."29 Unfortunately, she does not elaborate further as to how far those people had forged traditions. The number of the forged traditions is, of course, not so important. It could be many or just a few. However, when the practice of forgery is known to have happened, and the result of the practice has been handed down to the following generations together with the so-called genuine traditions, the generations which come after the era of the codified traditions from the forged ones. This is, for instance, clearly shown.by the collection of the Sahi'h al-Bukhori, which, though considered the most genuine among the six canonical collections, nevertheless is known to contain a number of weak traditions. ${ }^{30}$

More interesting still is her treatment regarding the position of the family isnäl; which strongly contradicts Schacht's conclusion. She is of the opinion that there was a positive parallel between the development of traditions and the development of the family isnōd relating to the chronological transmission of the traditions. ${ }^{31}$ Hence, the position of the family isnōd is seen as a confirmation of her conclusion that there is a clear continuation of the traditions. ${ }^{32}$

Schacht's conclusion concerning the position of the family isnōd is in opposition to Abbott's. While Abbott considers the family isnōd as a genuine transmitter of the traditions, Schacht considers it "not an indication of authenticity but only a device for securing its [tradition's] appearance." 33 This view is actually an elaboration of his general conclusion that the isn $\bar{a} d$ were improved. By providing certain proofs ${ }^{34}$ he concludes that "the most perfect and complete of isnōds are the latest." 35

As pointed out previously, Abbott does not directly dispute Schacht's discovery. Therefore, it is understandable that she does not directly verify the evidence of family isno $d$ given by Schacht, but rather consistently bases her argument on the critical analysis of her own data. Further investigation is, of course, needed in order to clarify this issue.

Another scholar who in recent years has thrown light on the problem of the authenticity of Arabic literature including traditions, is Fuat Sezgin. In the same year that Abbott published her Studies in Arabic

29 Abbott, Studies, 53.

30 See, for ecample, Rahman, Islamic Méthodology, 72; G.H.A. Juynboll, The: Authenticity of the Tradition Literature : Discussion in Modern Egypt (Leiden : E.J. Brill, 1969), 1.

31 Abbott, Studies, 37.

32 Ibid., 39

33 Schacht, Origins, 170. See also his "Islamic Traditions," 147.

34 Schacht, Origins, $170-1$.

35 Ibid., 165. 
Literary Papyri, he produced the first volume of his Geschichte des arabischen Schriftums, ${ }^{36}$ and it has been seen as one of the most significant contributions in the field. In a lengthy analysis of the tradition literature, Sezgin comes to the same conclusion as Abbott. ${ }^{37}$ By examining a large number of Arabic manuscripts, and by analysing the formulas used by the transmitters he insists that the common practice among Muslim scholars of writing down traditions started earlier than Goldziher has suggested, ${ }^{38}$ and finally comes to the conclusion that "the process of recording had th began during the lifetime of Muhammad and continued in an uninterupted in an uninterrupted fashion until the emergence of the great hadi th collections of the third/ninth century. "39

The word kitäb has been seen as a key in Sezgin's analysis, proving that the transmission of written sources, including the traditions, had started from an early time in Islamic hsitory. The frequent statements of the word kitäb used in Arabic literature, according to him, "must not be interpreted to signify an aversion to writing and an expression of prejudice in favor of oral transmission," 40 but rather is to be understood "as referring to an instructional procedure (kitäb, kitäbah, mukätabah) relying on written materials provided by the teacher." 41 He supports his thesis by' referring to the report conceming the statement made by al-Zuhri relating to his writing down "knowledge" ('ilm) in response to requests by the Ummayads. Al Zuhrí said : kunnānakrahu kitāb al-ilmi hautā akrahanà 'alaihi hä'ulä'i al-'umarä fara'ainā aniā namna'ahü ahadan min al-muslimin." Unlike Goldziher who interpreted kitab al-'ilm as process of fabrication, Sezgin interprets the term kitäb on the same lines as kitäbah and mukätabah, and comes to the viewpoint which is supported by Nawawi and Abū Nu'aim that the Umayyads forced alZuhri (and other traditionists) "not simply to write the traditions down but to practice the transmission procedure of mukätaba." 42

Sezgin's work, however, has been subjected to criticism. His data, as is the case with other works in the field, are seriously questioned on the basis of their authenticity, for they were documents only

36 Leiden : E.J. Brill, 1967. Sezgin's work has been seen as "expansion, correction, and updating of Brockelmann's basic study of the history of Arabic literature," and covers "an extensive manuscript concerning Qur'änic sciences, tradition, history, law, dogma, and mysticism with special attention to translations from the Sanskrit, Pahlavi, Syriac, and Greek works" (see Adams, "Religious Tradition," 67, and Nabia Abbott, review of Geschichle des arabischen Schrifitums, by Fuat Sezgin, in Journal of Near Eastern Studies 29, 1970 : 57).

37 Because of her enthusiasm for supporting Sezgin's' work (in order to confirm indirectly her own thesis) Abbott does not address even the slightest criticism to Sezgin's theories (see her review of Sezgin's work, 57).

38 Juynboll, Authenticity, 3.

39 David S. Powers, Studies in Qur,än and Hadith : The Formation of the Islamic Law of Inheritance (Los Angeles : University of California Press, 1986), 5.

40 Franz Rosenthal, review of Geschichte des Arabischen Schriftums, by Fuat Sezgin, in JAOS 89 (1969) : 294.

41 Ibid.

42 Juynboll, Authenticity, 113. 
from after the first century of hijrah, and, according to Juynboll, the evidences themselves postdate the era of, as everybody is bound to agree, wider-scale forgery of tradition, either in terms of its matn or its isnad. 43

Other correction addressed to Sezgin's work concerns the author of the Kit ab alaläh 'alä al-Nabí. This work, according to Rosenthal, is not by, as claimed by Sezgin, Abū Bakr Ahmạd B. 'Amr alBazzār, but rather by Abu Bakr Ahmad b. 'Amr b. Abí 'Așim an-Nabī. ${ }^{44}$

Perhaps we will agree with Juynboll ${ }^{45}$ that until the present time M. Mustafa Azami ${ }^{46}$ is the scholar who has provided "the most articulate critique" of Schacht's thesis regarding the authenticity of tradition. Azami formulates his thesis in his Studies in Early Hadith Literature, ${ }^{47}$ particularly in part one, chapters six and seven, and elaborates his more serious critique. of Schacht's thesis in his subsequent book On Schacht's Origins of Muhammadan Jurisprudence. ${ }^{48}$

Azami successfully demonstrates that the process of collecting traditions had begun during the time of Muhammad. He calculates, for instance, 47 cases and examples discussed by Schacht and examines 24 , of them ${ }^{49}$ which lead him to the following conclusion :

Careful scrutiny of his [Schacht's] examples and repeated reference to the original source material, however, reveals inconsistencies both within the theory it self and in the use of source material, unwarranted assumptions and unscientific method of research, mistakes of fact, ignorance of the political and geographical realities of the time, and misinterpretation of the meaning of the texts quoted, and misunderstanding of the method of quotation of early scholars. ${ }^{50}$

Schacht's conclusions regarding the authenticity of traditions, as we know, go hand in hand with his other conclusion regarding the origin of Islamic jurisprudence, as shown clearly in the title of his first book. Therefore it is

43

G.H.A. Juynboll, Muslim Tradition : Studies in Chronology, Provenance and Authorship of Early Hadith (Cambridge : Cambridge University Press, 1983), 4.

44 Rosenthal, review of Geschichte, 294.

45 Juynboll, Muslim Tradition, 3, 207.

$46 \mathrm{He}$ is Professor of hadith science at King Saud University, Saudi Arabia since 1973. He obtained his Ph. D. in Islamic Studies from Cambridge University in 1967, and studied at alAzhar University of Egypt and at Där al--Ulüm of India. In 1980 he received the prestigious King Faisal Award from his research and presentations on the sunnah. Another interesting work of his the computerization of the hadith (see the back cover of his On Schacht's Origins of Muhammadan Jurisprudence, Saudi Arabia : King Saud University Preș, 1985).

47 His doctoral dissertation at Cambridge University in 1966, and published in Beirut in 1968 by al-Maktab al-Islami which is now also available in an Arabic translation -under the title Dirāsät fi al-Hadith al-Nabawi wa-Tärikh Tadwinih, published in Beirut in 1973, and in Riyạ̄ in 1976 and 1979.

48 Saudi Arabia : King Saud University Press, 1985.

49 There is no clear explanation for why he examines just 24 from the 47 cases listed in his book.

50 Azami, Schacht's Origins, 116. See also his paraphrase of this conclusion in page 3 . 
understandable that Schacht concentrates his critical analysis more on legal traditions instead of tradition in general. It is on this point that Azami challenges Schacht's approach. In Azami's view, it is quite wrong to study traditions as a subject by limiting them to the legal tradition literature alone, and he emphasizes that "any conclusion about the traditions, their transmission, or the isnäd system, etc, based on the study of legal literature would be faulty and unreliable." 51 However, it is very unfortunate that Azami never touches on the reason given by Schacht as to why he concentrates his analysis more on legal tradition. Schacht argues :

Law is a particularly good subject on which to develop and test a method which claims to provide objective criteria for a critical approach to Islamic traditions, and that for two reasons. Firstly, our literary sources carry us back in law further than, say, in history, and for the crucial second century they are much more abundant on law than on any other subject. Secondly, our judgment on the formal and abstract problems of law and legal science is less likely to be distorted by pre-conceived ideas (those expressed in our sources as well as our own), than if we had to judge directly on issues of political and religious history of Islam. 52

Schacht's method is certainly supported by the fact that the contents of the Muwatta of Malik and the six books of tradition, al-kutub al-sittah, which have traditionally been seen as the authoritative works in the field, are obviously arranged in accordance with the arrangement of the subject-matter of law, $a l-a b w a ̈ b a l$ fiqhiyyah.
The other point raised by Azami is Schacht's suspicion about the isn $\bar{a} d$ of Malik -- Năfi' -- Ibn 'Umar which is based on two grounds : the age of Malik and the position of Nãfi as the client of Ibn 'Umar. Schacht writes : "But as Năfi' died in A.H. 117 or thereabouts, and Mālik in A.H. 179, their association can have taken place, even at the most generous estimate, only when Mâlik was little more than a boy." 53 Azami lays the blame on Schacht's omission of the birth date of Malik, which, according to him, "can lead only to erroneous conclusions." 54 Then he writes :

Had he [Schacht] consulted any bibliographical work he would have - found that most of the scholars, even those who were bom a little earlier than Mãlik, state that he was bom in $93 \mathrm{A.H} ;$ a few put it in the early moths of 94 A.H., a few in 90 A.H. and a few in 97. But there is no one who maintains any date later than this. So, Malik was at least twenty years old, if not twenty-four or twenty-seven, when Nāfì died. ${ }^{55}$

This issue is very interesting and has given rise to certain questions' such as : why does Schacht not mention the birth date of

51 M. Mustafa Azami, Studies in Early Hadith Literalure (Saudi Arabia : King Saud University Press, 1985), 222. 144.

52 Joseph Schacht, "Islamic Traditions,"

53 Schacht, Origins, $176-7$.

54 Azami, Studies, 245.

55 Ibid. 
Malik? Does he consider the date as not. authentic ? It is important to note here that Schacht writes: "Nothing authentic is known of Màlik's date of birth," 56 and he does not say there is not any data relating to this issue.

To support his idea that the isnād of Malik-Näfi'--Ibn 'Umar ' is unquestionable, Azami, challenges viewpoint concerning the position of Nāfi' as the client of Ibn 'Umar in relation to the transmission of traditions. 'Unfortunately, without analysing Schacht's argument, Azami provides only a general conclusion, saying : "...if a man is being accepted amongst his contemporaries and among the later authorities as most trustworthy, then why should he be dishonest ? If a statement of a father about his son or vice versa, or - a wife about her husband or a friend about a friend or a colleague is always unacceptable, then on what sources could a biography possibly be written ?."57 It is certainly beyond question that Schacht's treatment of Nâfi's position obviously corroborates his general idea of the family isnōd, and the case of $\mathrm{Nafi}^{-}$ leads support to his view that legal traditions originated in the first half of the second century A.H. 58

To my knowledge Azami's work has not received much attention from later scholars such as David F. Forte, 59 L.T. Librande, 60 Marlyn Robinson Waldman, ${ }^{61}$ Rafael Talmon, ${ }^{62}$ Charles J. Adams, ${ }^{63}$ and Zafár Ishạa An șain , ${ }^{64}$ to mention just a few. Schacht never addressed Azami's work. More interesting still is the absence of reviews of Azami's work by Western scholars, when in fact he is a recognized expert on the science of traditions and has received an award for his career from King Abdul Aziz University, Saudi Arabia. More than this, his Studies has been considered as, at least. by Arberry, "one of the most exciting and original investigations in this field of modern times." 65

56 Schacht, Origins, 176 footnote 4.'

57 Azami, Studies, 245. In the same way he repeated this conclusion in a paraphrase form when he discusses the family isnäd (see his Schacht's Origins, 196 - 7).

58 See his Origins, $170-1,176$ - 9. Schacht chooses the isnäd group of Malik--Nafi --Ibn Umar because of three reasons: the available sources are most complete on 'the Medinese, the Nafi' traditions are the most important single group of "Medinese traditions, and the isnād Malik--Naff'--Ibn 'Umar is one of the best, if not the very best, according to the Muslim scholars.

59 See his article "Islamic Law".

60 See his article "Hadith" in The Encyclopedia of Religion, ed: Mircea Eliade.

61 See her article "Sunnah," in The Encyclopedia of Religion, ed. Mircea Eliade.

62 See his "Schacht's Theory in the Light of Recent Discoveries Concerning and the Origins of Arabic Grammar," Studia Islamica 61 (1987) : $31-50$.

63 See his "Religious Tradition."

64 When he cites some works which contradict Goldziher's and Schacht's viewpoints he refers to the work of Abbott and Sezgin without mentioning the work of Azami at all (see his "The authenticity of Traditions: A Critique of Joseph Schacht's Argument $e$ silentio,". Hamdard Islamicus 7, 1984 : 59 footnote 2).

65 See Arberry's "Foreword" in Azami's Siudies. This is also cited by Muhammad Hamidullah in his review of Azami's work in Revue Des Etudes Islamiques 37 (1969) : 373. 
Zafãr Isḥāq Anșāiñ ${ }^{-66}$ can also be included among those scholars who have seriously challenged Schacht's thesis. His challenge is not execlusively addressed to Schacht's sceptical attitude towards the Prophetic traditions, but rather to Westem scholarship in general. Nonetheless, it is a fact that most of his arguments, as far as the Prophetic traditions are concemed, are addressed to Schacht's thesis. For, in his view, Schacht's thesis is "the most impressive and the best argued presentation" in Western scholarship. ${ }^{67}$ His critique is primarily addressed to Schacht's argument $e$ silentio, ${ }^{68}$ and he has aptly remarked : "there were several considerations which show that mechanical application of the $e$ silentio argument...is unjustified," 69 then he emphasizes this conclusive remark in his later work, saying: "Schacht's 'methodical rule' and his line of argumentation are highly sweeping. ${ }^{70}$

The argument $e$ silentio, as we know, is the main approach used by Schacht to examine Prophetic traditions and which, on the basis of sufficient data, leads him to the conclusion that "we shall not meet any legal tradition from the Prophet which can be considered authentic." 71

Having analysed Schacht's argument and its data, Anșäă charges Schacht with not being consistent in his own argument. For, according to Anșāñ , Schacht also uses later sources (e.g. fifth century sources) to support his viewpoint regarding certain doctrines which occurred in the first and second centuries. Anșāi proves the inconsistency of Schacht's own argument, by showing that schacht, for instance, "cites an argument of Shaibāin in favour of a doctrine of his school...on the basis of a late fifth century book viz., Sarakhsi, Mabșüt." 72

Aside form the fact that An șañ has thrown light on Schacht's inconsistencies, he is also able to demonstrate the absurdity of Schacht's thesis by tuming the method upside down, that is, by examining the traditions found in early works that are not found in the later works. "This would mean, "Anșāñ remarks," Working on the

$66 \mathrm{He}$ is Professor of History at University of Petroleum and Minerals, Dhahran, Saudi Arabia. He obtained his $\mathrm{Ph}$. D. in Islamic studies from Institute of Islamic Studies McGill University in 1966 (see Khurshid Ahmad and Zafar Ishäq Anșari, eds. Islamic Perspectives : Studies in. Honour of Mawlāna Sayyid Abul A lä Mawdüdi, Saudi Arabia : Saudi Publishing House, 1979, xv).

67 Zafar Ishaq Anșari,. "The Early Development of Islamic Fiqh in Küfah with Special Reference to the Works of Abù Yüsuf and shaibāni" (Ph.D. diss. Montreal : McGill University, 1966), 235.

$68 \mathrm{He}$ elaborates his critique in his dissertation, 52 - 66 and 234 - 43. The last part (234-43), with some changes of words and/or sentences, appeared in his article "Authenticity." This view is adopted later by Azami (see his Studies, 254 - 5, and his Schacht's Origins, 118 22).

69 Anșāì, "Early Development," 64.

70 Anșārī, "Authenticity," 53.

71 Schacht, Origins, 149. For Schacht's use of the argument, see, for ecample, his Origins, $140-1$.

72 See his "Early Development," 518 footnote 214 . 
reverse of Schacht's assumption."73 In order to prove his argument, Anșāñ conducted a test on four books : the Muwatta's of Māilik and of Shaibān', and the Áthärs of Ab u Y usuf and of Shaibāní, by examining the traditions which discuss the same issues. The result is quite impressive. There is a large number of traditions found in the Muwatta' of Màlik that are not found in the Muwatta of Shaibāñ ${ }^{-74}$ and a number found in the $\bar{A}$ thär of Abū Y usuf that are not found in the $\vec{A}$ thär of Shaibāri- ${ }^{-75}$ An șañ emphasizes tha fact that the Muwatța' of Shaibāin appeared later than the Muwa țta' of Mālik, and the $\bar{A}$ thär of Shaibāá appreared later than the $\bar{A}$ thār of Abū Y usuf. Anșān's result, as a consequence, seriously challenges Schacht's $e$ 'silentio argument which states: "The best way of proving that a tradition did not exist at a certain time is to show that it was not used as a legal argument in a discussion which would have made reference to it imperative, if it had existed." 76

Certain questions may be raised here as to why the later scholars do not mention the traditions which are found in earlier works in their discussions of the same issue. A variety of answers are highly possible. Anșair may be correct in that there is a great number of instances "where a jurist recorded the doctrine of his school on a legal question but did not care to cite the tradition which was relevant to, and/or was supportive of his doctrine, even though it can be incontrovertibly shown that he knew that tradition." 77 In fact, according to him, there are many doctrines derived from the Qur'an that were recorded without mentioning the relevant verses. ${ }^{78}$ However, it could also be possible that later jurists did not mention some traditions which were available in previous works, even though they could have supported their arguments, because of their consideration that the traditions were not authentic.

Anșāin has also called Schacht's view that there is not a single Prophetic tradition considered genuine "grossly exaggerated," while it is clear that, according to him, quite a number of Prophetic traditions are forged and fabricated by later generations, ${ }^{79}$ However, it could also be possible that later jurists did not mention some traditions which were available in previous works, even though they could have supported their arguments, because of their consideration that the traditions were not authentic.

Anșāin has also called Schacht's view that there is not a single Prophetic tradition considered genuine "grossly exaggerated," while it is clear that, according to him, quite a number of Prophetic traditions are forged and fabricated by later

73 Anșārī, "Aựhenticity," 54.

74 For more details, see his "Early Development," 237 - 40, and his "Authenticity," $56-7$.

75 For more details, see his "Early Development," $240-1$, and his "Authenticity," 57.

76 Schacht, Origins, 140.

77 See his "Early Development," 237; his "Authenticity," 54.

78 See his "Early Development," 236; his "Authenticity," 54.

79 See his "Early Development," 58, 61, 65 6. 
generations, ${ }^{79}$ nevertheless, this fact, he strongly argues, "does not exclude the possibility that quite a number of Prophetic traditions do genuinely go back to the Prophet." 80 A clear criterion to distinguish the genuine tradition from the forged one is, in his viewpoint, badly needed. Nonetheless, without clear explanation, he refers to the science of dirayah which, according to him, has long. been well-known among Muslim scholars. 81

In 1972 Anșäri published an article 82 which, though it does not directly dispute Schacht's thesis, develops an argument that challenges Schacht's conclusions. In this article he is concerned with the semantic analysis of some of the important terms used in figh during the early period of Islam, terms such as hadt th, sunnah, etc. ${ }^{83}$ The most important result of his notion that at the same time significantly contradicts Schacht's conclusion is his notion that the phrases "hadith of the Prophet" and "sunnah of the Prophet" have positively been used since early times, in fact from a period close to the lifetime of the Prophet. ${ }^{84}$ Moreover, there is an indication, according to him, that since quite early times, at least among the muhaddithün, the terms hadi th and sunnah were used interchangeably. 85

Anșān's analytical study of the development of the terms sunnah through a variety of sources, particularly the works of Abū Yūsuf and of Shaibāñ', is undoubtedly important for any scholar who studies the historical development of traditions. Unfortunately, even though he has successfully provided the positive proof that the term sunnah does not exclusively refer to the Prophet, but also to the Companions, fuqahā', and sometimes also to the virtuous people (as a good example), he has failed in the end to draw a line between the sunnah of the Prophet and the other sunnahs. It is not an easy task to do so, we believe. Nevertheless, it is a cause for great regret, for the most controversial issue among scholars relating to the authenticity of traditions is, among others, the criteria for verifying the Muslim claim that the Prophetic traditions are undoubtedly rooted in the Prophet himself.

80 See his "Early Development," 66.

81 Ibid., 418 footnote 94.

82 "Islamic Juristic Terminology before Sāfi'i : A Semantic Analysis with Special Reference to Küfa," Arabica 19 (October 1972) : 255-300. This article is, actually, the first part of his dissertation, $120-177$.

83 Ansāin claims that this study is very important to avoid the ambiquous understanding of the early history of Islam, e.g. Islamic jurisprudence. This ambiguity is, according to him, sometimes shown by the use of certain a term "in a multiplicity of meanings by one and the same author and often in the same work." Ansări examines the historical development of meaning of both hadith and sunnah through the following stages: 1 . hadith: the use of the term in early Islamic literature (265), and of the works. of the second century school such as Abū Yüsuf and Shaibani $(256-8)$. 2. Sunnah : the literal meaning (259-61), the meaning used in the Qur'an (261 - 3), the meaning addressed to certain people : 'Umar, al-Hassan al-Basri, and Abd. B. "Ibād (63-4), in the second century works of Ib́n al-Muqaffa', Awzzāì Mālik, Abū Yūsuf, and Shaibāni (265-71).

\section{See his "Islamic Juristic," 256-82.}

85 Ibid., 258, 273. athār, riwäyah, and khabar were other terms used more less interchangeably with hadith (see ibid., 256). 


\section{Concluding Remarks.}

Our discussion in this essay has tried to provide an analysis of the response of some prominent scholars to Schacht's thesis regarding the authenticity of traditions. I would like to conclude with the following remarks.

The central role of Muhammad among Muslims as the expounder of the Qur'an, ${ }^{86}$ the legislator, ${ }^{87}$ the one to be obeyed, ${ }^{88}$ and the example of Muślim conduct and behaviour ${ }^{89}$ is certainly beyond question. This suggests that the guiding authority of Allah and was explicitly prescribed by Allah himself. ${ }^{90}$ Al pious Muslims therefore are extremely eager to perform all the activities of their daily life in accordance with Muhammad's saying (qawl), action (fil), and tacitapproval (taqri $r$ ), the body of which is well-known later as the Prophetic traditions. By the end of the third century of the Muslim era the final authoritative collections were complete. 'These collections of traditions (prepared by alBukhārī, Muslim, Abū Dāwud, al'Nasāìi, Timidhí, and Ibn Mājah) ăre considered to be the most reliable compilations as this source of Islamic law.

In modem times, a serious debate has raged as to whether or not traditions - orginated in their entirety with Muhammad himself. Joseph Schacht has endeavoured to examine the authenticity of the traditions and comes to the convincing conclusion that no single tradition originated with Mühammad. Rahman, Abbott, Sezgin, Azami, and Anșar̃ have provided various responses to Schacht's thesis and finally come to conclusions which are at odds with Schacht's. :
Some important points should be made here. The most crucial problem of our discussion is the absence of written documents from the first century of Islam.

86 Qur'an 16 (44) : "We have revealed unto thee the Remembrance that thou mayst explain to. mankind that which hath been revealed for them, and that haply they may reflect" (all of the Quranic verses in this essay are quoted from Mohammed Marmaduke Picthall, The Meaning of the Glorious Koran (Ontario : Penguin Books, n.d.).

87. Qur'an 7 (157): "Those who follow the messenger, the Prophet who can neither read nor write, whom they will find described in the Rorah and the Gospel (which are) with them. He will enjoin on them that which is right and forbid them that which is wrong. He will make lawful for them all good things and prohibit for them only the foul; and he will relieve them of their 'burden and the fetters that they used to wear. Then those who believe in him, and honour him, and help him, and follow the light which is sent down with him : they are the successful".

${ }^{88}$ Quran 4 (64): "We sent no messenger save that he should be obeyed by Allah's leave." 3 (32): "Say: Obey Allah and the obey: the messenger and those of you who are in authority; and if ye have a dispute concerning any matter, refer it to Allah and the messenger if ye are (in truth) believers in Allah and the Last Day. That is better and more seemly in the end:" 4 (80): "Whoso obeyeth the messenger obeyeth Allah, and whoso turneth away : We have not sent thee as a warder over them."

89 Qur'an 33 (21) : "Verily in the messenger" of Allah ye have' a good example for him who looketh unto Allah and the Last Day, and remembereth Allah much."

90 Qur'an 59 (7): "and whatsoever the messenger giveth you, take it. And whatsoever he forbiddeth, abstain (from it). And keep your duty to Allah. Lo! Allah is stem in reprisal." 4 (65): "But nay, by thy Lord, they will not believe (in truth) until they make thee judge of what is in dispute between them and find within themselves no dislike of that which thou decidest, and submit with full submission." 
This situation has led to a polemical viewpoint among Islamic scholars concering the authenticity of traditions and Islamic history in general. In addition to this, Schacht and his opponents seem to be persistent in advancing their own theories and base their analyses on their own examples and on data that suit their general hypotheses and support the conclusions which they have apparently made before undertaking their research. It is supported by the fact that some of the scholars are selectively silent and do not analyse the data of their opponents which do not support their own thesis.

Another point that needs to be raised here is the fact that the style of Arabic in the traditions deserves more research on the part of scholars. Any one who is familiar with the Qurān and the traditions would accept our general contention that the Arabic style used in the Qur'ân is different from that used in the traditions. The Arabic style used in the Qur'ân, according to the report of historians, originated in pre-Islamic Arabia and is called "Classical Arabic." On the other hand, if we agree that the traditions started after the first century A.H., it will be clear that the Arabic style used in the traditions is representative of "Middle Arabic," a variety in which local language (in area conquered by Muslims), according to Hawting, had affected the original Arabic. 91 Our assumption here would seem to be in keeping with Schacht's thesis that the traditions, or at least their from if not their substance, 92 appeared after the first century A.H.

I can think of no more appropriate way of ending these concluding remarks than by quoting a passage from Coulson's article "European Ciriticism of Hadith Literature" :

In such cases, then, it may be that the truth lies somewhere between traditional Islamic legal theory and the rigorous historical approch of Schacht. At the same time it must, of course, be frankly recognized that the Muslim and the Western methods of $H \bar{a}$ ith criticism are irreconcilable because they rest upon totally different premises. Between the dictates of religious faith on the one.hand and secular historical criticism on the other there can be no middle way of true objectivity. 93

\section{SELECTED BIBLIOGRAPHY}

Abbott, Nabia. "Hadith Literature : Collection and Transmission of Hadit th." In Arabic Literature to the End of the Umayyad Period, eds. A.F.L. Beeston and others, 28998. Cambridge : Cambridge University Press, 1983.

91 G.R. Hawting present the general charasteristic of Classical Arabic and Middle Arabic in his The First Dynasty of Islam (London: Croom Helm Ltd., 1986), 9-10.

92 Guillaume has raised a good point, saying: "it seems somewhat too drastic to postulate that 'every legal tradition from the prophet until the contrary is proved must be taken not as an authentic...., unless we are to understand that Dr. Schacht refers to the form rather than, to the substance of the tradition." (see his review of Schacht's Origins, in Bulletin of the School of Oriental and African Studies 16, 1954: 176).

93 N.J. Coulson, "European Criticism of Hadith Literature," in Arabic Literature to the End of the Umayyad Period, 321. 
........ Review of Geschichte des Arabischen Schrifttums, by Fuat Sezgin. In Journal of Near Eastern Studies 29 (1970) : 57.

......... Studies in Arabic Literary Papyri. Volume 2. Chicago : The University of Chicago Press, 1957. Adams, Charles J. "Islamic Religious Tradition." In The Study of the Middle East: Research and Scholarship in the Humanities and Social Science, ed. Leonard Binder, 29-95. New York: John Wiley \& Sons, 1976.

Ahmad, Khurshid and Zafâr Ishāāq Ansāñ, eds. Islamic Perspectives: Studies in Honour of Mawlanà sayyid Abul A lā Mawdūá. Saudi Arabià : Saudi Publishing House, 1979.

Anderson, J.N.D. Review of The Origins of Muhammadan Jurisprudence, by Joseph Schacht. In Welt des Islams 2 (1952): 136.

Anșạ̄in, Zaf àr Ishạà. "Islamic Juristic Terminology before Sāfi $\bar{i}$ : A semantic analysis with Special Reference to Küfa." Arabica 19 (October 1972): 255-300.

"The authenticity of Tradition: A Critique of Joseph Schacht's Argument $e$ silentio." Hamdard Islamicus 7 (1984): 51-61.

"The Early Development of Islamic Fiqh in Kufah with Special Reference to the Works of Abū Yüsuf and Shaibāñ ". Ph.D. Diss. Montreal : McGill University, 1966.

Azami, M. Mustafa. On Schacht's Origins of Muhammadan Jurisprudence. Saudi Arabia: King Saud University ' Press, 1985. Studies in Early Hadit th Literature.
Beirut: al-Maktab al-Islāmí, 1968.

Burton, John. Review of Islam, by Fazlur Rahman. In BSOAS 31 (1968): 392-5.

Coulson, N.J. "European Criticsm of Hadi th Literature." In Arabic Literature to the End of the Umayyad Period, eds. A.F.L. Beeston and others, 317-21. Cambridge: Cambridge University Press, 1983.

Denny, Frederick Mathewson. "Fazlur Rahman: Muslim Intellectual." The Muslim LXXIX (April 1989): 91101.

Eliade, Mircea, ed. The Encyclopedia of Religion. London: Macmillan Publishing Company, 1987, s.v. "Hadíth," by L.T. Librande; s.v. "Sunnah," by Marilyn Robinson - Waldman.

Forte, David F. "Islamic Law: The Impact of Joseph Schacht." Loyola of Los Angeles International and Comparative Law Annual 1 (1978): 1 - 36 .

Guillaume, Alfred. Review of The Origins of Muhammadan Jurispridence, by Joseph Schacht. In BSOAS 16 (1954) : 176 - 7.

Hamidullah, Mohammad. Review of . Studies in Early Hadi th Literature, by M. Mustafa Azami. In Revue Des Etudes Islamiques 37 (1969) : 373 - 4.

Hawting, G.R. The First Dynasty of Islam. London: Croom Helm Ltd., 1986.

Jeffery, Arthur. Review of The Origins of Muhammadan Jurisprudence, by Joseph Schacht. In Middle East Journal 5 (1951): 392 - 4.

Juynboll, G.H.A. Muslim Tradition: 
Studies in Chronology, Provenance and Authorship of Early Hadith. Cambridge : Cambridge University Press, 1983.

The Authenticity of the Tradition Literature: Discussion in Modern Egypt. Leiden : E.J. Brill, 1969.

Mahdi, Muhsin. "Foreword". Journal of Near Eastern Studies' 40 (July 1981).

Pickthall, Mohammed Marmaduke. The Meaning of the Glorious Koran. Ontario: Penguin Books, n.d.

Powers, David S. Studies in Qur'ōn and Hadith : The Formation of the Islamic Law of Inheritance. Los Angeles : University of Califomia Press, 1986.

Rahiman, Fazlur. Islam. Chicago : The University of Chicago Press, 1979. Islamic Methodology in History. Karachi : Central Institute of Islamic Research, 1965.

"Some. Issues in the Ayyūb Khān Era." In Essays on Islamic Civilization, ed. Donald P. Little, 284 - 302. Leiden: E.J. Brill, 1976. "The Status of Women in Islam : A Modernist Interpretation." In Separate World : Studies of Purdah in South Asia, eds. Hanna Papanek and Gail Minault, 285 - 310. Delhi: Kay Kay Printers, 1982.

Ritter, H. Review of The Origins of Muhammadan Jurisprudence, by Joseph Schacht. In Oriens 4 (1951) : $308-12$.

Robson, James. Review of Studies in Arabic Literary Papyri, volume 2, by Nabia Abbott. In 'Journal of Near Eastern'Studie's 27 (1968): 143 - 4.

........, Review of The Origins of Muhammadan Jurisprudence, by Joseph Schacht. In The Muslim World 42 (1952) : 61-3.

Rosenthal, Franz. Review of Geschichte des Arabischeinn Scrifttums, by Fuat Sezgin. In Journal of the American Oriental Society 89 (1969): 293 - 5.

Schacht, Joseph. An Introduction to Islamic Law. Oxford : Clarendon Press, 1964.

"A Revaluation of Islamic Traditions." JRAS (1949) : 143 54.

........., "Theology and Law in Islam." In Theology and Law in Islam, ed. G.E. von Grunebaum, 3 - 23. Wiesbaden : Otto Harrossowitz, 1971.

The Origins of Muhammadan Jurisprudence. Oxford : Clarendon Press, 1959.

Talmon, Rafael. "Schacht's Theory in the Light of Recent Discovery Concerning and the Origins of Arabic Grammar." Studia Islamica 65 (1987): 31-50.

Watt, W. Momtgomery. Review of The Origins of Muhammadan Jurisprudence, by Joseph Schacht. In JRAS (1952) : 91.

Wansbrough, J. Review of Studies in Arabic Literay Papyri, volume 2, by Nabia Abbott. In BSOAS 31 (1968) $: 614$. 


\section{RESENSI BUKU}

\section{Sudut Hukum Mengenai Tanggungjawab Keuangan Negara}

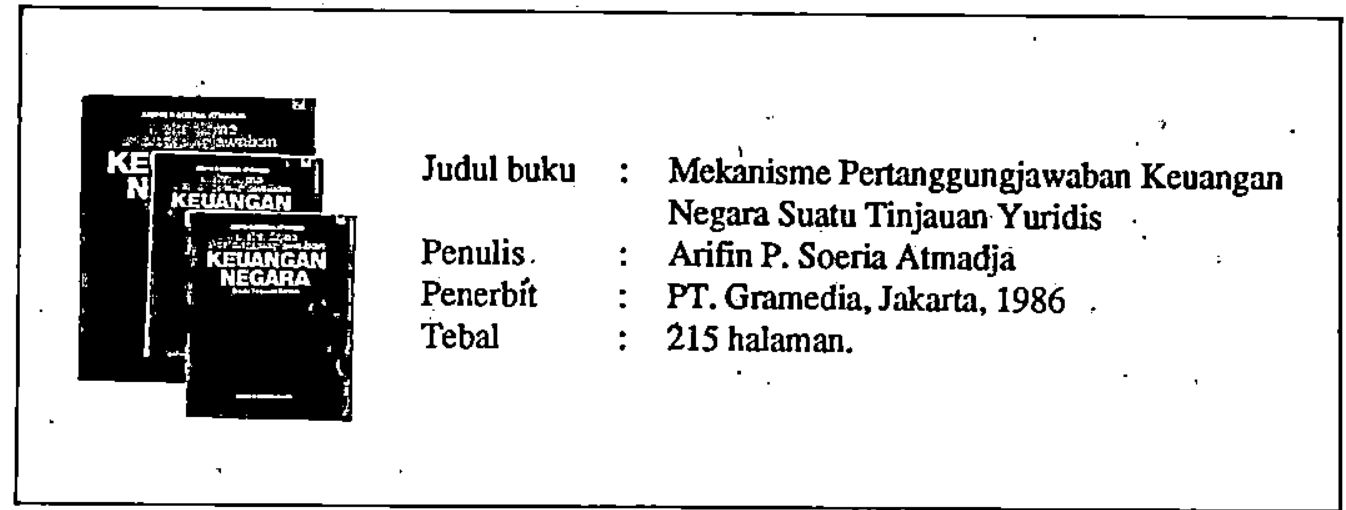

Kalau orang berbicara tentang APBN atau anggaran negara pada umumya maka biasanya bobot pembicaraan lebih ditekankan pada angka-angka atau perhitungan ekonomi. Jarang didapat pembicaraan mengenai ini. Pembicaraan ini masih sangat jarang dilihat dari sudut hukum, lebih-lebih kaitannya dengan pertanggung-jawaban.

Pada tahun 1983 Arifin P. Soeria Atmadja mempertahankan disertasi didepan Senat UNPAD Bandung dengan judul "Segi Hukum Mekanisme Pertanggungjawaban' Keuangan Negara Suatu Tinjauan Yuridis". Meskipun sudah lampau selama lebih kurang 9 tahun sejak dipertahankan dan 6 tahun sejak dipublikasikan tetapi permasalahan, kesimpulan, dan rekomendasi yang dimuat di dalạm buku ini tetap relevan dengan apa yang kita hadapi dan kita butuhkan dewasa ini.

Masalah pengelolaan dan pertanggungjawaban keuangan negara merupakan masalah sangat penting di dalam administrasi pemerintahan sebab keuangan negara itu merupakan "urat nadi kehidupan negara". Karenanya menjadi sangat penting pula adanya kepastian hukum méngenai mekanisme pengelolaan dan pertanggungjawaban keuangan negara. Buku ini membedah masalah-masalah yang penting itu dengan cukup tuntas.

Permasalahan pertama yang dianigkat dalam buku ini adalah adanya dualisme hukum mengenai anggaran negara. Dikatakan bahwa dalam rangka penyelenggaraan pemerintahan" rutin cukup 
banyak dana yang dipergunakan yang sumbernya bisa berasal dari luar negeri maupun dari dalam negeri. Masalahnya, dasar hukum pengelolaan anggaran itu sekarang ada dua yaitu UUD 1945 (pasal 23) dan Indische Compatibiliteitswet (ICW) 1925 yang berlaku sejak jaman kolonial Belanda; dan pemberlakuannya itu didasarkan pada aturan peralihan pasal II UUD 1945. Tentang keberlakuan ICW 1925 ini bahkan setiap UU APBN selalu menyebut secara eksplisit bahwa ketentuan-ketentuan ICW 1925 yang bertentangan dengan bentuk, susunan, dan isi UU APBN 1925 dinyatakan tidak berlaku; artinya ICW tetap berlaku pada segi-segi yang tidak bertentangan dengan UU APBN dalam bentuk, susunan, dan isinya.

Dari segi pengertian yuridis secara formal dan material ditegaskan bahwa sebenamya aturan UU APBN dan ICW 1925 terdapat perbedaan bobot sebab UU APBN hanya mempunyai bobot formal sedangkan ICW 1925 mempunyai bobot formal dan material sekaligus. Karena bobotnya yang seperti itu ICW dipandang sebagai UU Pelaksanaan UU APBN sepanjang bentuk, susunan, dan isinya tidak bertentangan dengan UU APBN itu. Disinilah timbulnya "dualisme" keberlakuan peraturan perundangundangan tentang anggaran negara itu segera nampak; sebab sejak 1980 Presiden teiah mengeluarkan Kepres bemomor $14 \mathrm{~A}$ tahun 1980 yang ternyata merupakan Peraturan Pelaksanaan terhadap APBN. Jadinya ada dua peraturan pelaksanaan APBN yang berlaku secara bersama, yảitu, ICW (karena bobot formal dan materialnya) dan Kepres no. 14 A tahun 1980 (Kepres ini sudah pemah diubah dan diperbaharui dengan Kepres baru tentang hal yang sama tetapi secara prinsip materinya tetap sama). Persoalannya adalah : manakah yang harus dianut secara yuridis dan praktis?

Kalau saja kedua peraturan perundangundangan tersebut memuat materi yang sama atau saling mlengkapi maka pertanyaan tentang "manakah" itu tak perlu timbul. Namun keduanya disamping berbeda secara hirarkial, ternyata memuat pula perbedaan materi yang dalam buku ini disebutkan, antara lain, adanya pergeseran wewenang. Jika didasarkan pada tata urutan peraturan perundang-undangan sebagaimana diatur di dalam TAP MPR No. XX/1966 maka Kepres No. 14 A jelas derajatnya lebih rendah dari ICW 1925 sehingga tak mungkin mengesampingkan ICW itu; apalagi Kepres No. 14 A 1980 yang bersumber pada UU PABN hanyalah memiliki bobot formal. Tapi secara hakiki Kepres No. 14 A 1980 ini telah menambah dan mengubah ketentuan material ICW. Lihatlah misalnya tentang pergeseran wewenang dan tanggung jawab : menurut Kepres No. 14 A/ 1980 bendaharawan hanya bertanggungjawab kepada, atasan langsung, sedangkan menurut ICW (pasal 77) bendahärawan itu bertanggungjawab kepada BPK dan képada atasan langsung. Begitu juga wewenang menjadi bergeser karena menurut Kepres 14 A / 1980 bendaharawan lebih berfungsi sebagai juru bayar atas perintah kepala kantor/satuan kerja/pemimpin proyek, pada hal menurut ICW bendaharawan itu diserahi tugas menerima, menyimpan, dan atas perintah mengeluarkan uang atau barang milik negara yang bertanggung jawab kẻpada BPK; namun demikian menurut ICW bendaharawan itu dapat menolak untuk menerima atau mengeluarkan uang/barang 
atas perintah atasan seandainya bertentangan dengan ketentuan peraturan perundang - undangan.

Arifin mengkhawatirkan timbulnya kolusi dari konstelasi hubungan administrasi keuangan negara yang seperit ini.

Persoalan yang juga muncul adalah ini: bagaimana mekanisme pertanggungjawaban untuk mengimplementasikan pasal 23 (5) UUD 1945 dan kepada lembaga negara mana pemerintah menyampaikan laporan pertanggung jawaban keuangan? Memang secara mikro bendaharawan bertanggungjawab secara vertikal dan secara makro (sesuai pasal 23 (5) UUD 1945) BEPEKA memeriksa tanggungjawab keuangan negara yang dikelola oleh pemerintah. Namun bagaimana mekanisme untuk itu tidak jelas dukungan yuridisnya, dan kepada lembaga negara mana pemerintah menyampaikan tanggungjawab keuángan negara itu belum ada perumusan yuridisnya.

Tampak jelas bahwa ada dilema dalam hal anggaran negara ini yakni dilema pelaksanaan Peraturan perundangundangan ICW 1925 dan Kepres No. 14 A tahun 1980 (tentu dengan KepresKepres yang memperbaharuinya) yang pada gilirannya berimplikasi timbulnya dualisme hukum di bịdang pengelolaan dan pertanggung-jawaban keuangan negara. Hal ini tidak dapat dihindari mengingat kenyataan pelaksanaan pembangunan tidak selalu sejalan dèngan keberlakuan suatu peraturan perundangundangan. Kepres No. 14 A oleh penulis dipandang sebagai terobosan yang dilakukan oleh pemerintah untuk mengisi kesenjangan hukum yang dibutuhkan oleh pembangunan; dan Kepres tersebut dapat dilihat sebagai perubahan dan tambahan terhadap materi ICW' 1925.

Kesimpulan pertama dari buku ini menyebutkan bahwa ICW sebagai UU organik yang menjabarkan pasal 23 UUD 1945 adalah tidak sesuai, baik ditinjau dari. segi yuridis maupun dari sudut operasional, dalam konstelasi ketatanegaraan RI. Tetapi tetap berlakunya ICW tetap melanggengkan dualisme hukum yang kendati bersifat luwes dan akomodatif sebenamya akan menimbulkan dampak negatif dalam jangka panjang karena selalu dihadapkan pada pilihan yang lebih bersifat kebijaksanaan temporer daripada peraturan perundang-undangan yang mapan. Oleh karena itu penulis merekomendasikan dibuatnya UU tentang perbendaharaan Negara yang dapat menggantikan ICW, yang sebenarnya secara idiil dan konstitusional memang sejak lama harus diganti.

Hal lain yang disimpulkan oleh penulis, dan agaknya aneh jika dilihat dari rumusan pasal 23 (5) UUD 1945, adalah bahwa seharusnya Pemerintah sebagai pemegang kuasa dari DPR untuk melaksanakan APBN mempertanggungjawabkan pengelolaan keuangan negara itu kepada DPR yang memiliki hak bergrooting dan memberikan kuasa itu; jadi bukan kepada BPK. Mekanisme pertanggungjawaban APBN tersebut sebaiknya dituangkan di dalam Tap MPR atau UU Perbendaharaan Negara (yang hendaknya segera dibuat), dan tidak sekedar didasarkan semata-mata pada salah satu pasal UU APBN yang hanya bersifat formal dan temporal itu.

Moh. Mahfud MD. 